\title{
Loss of adherence ability to human gingival epithelial cells in S-layer protein-deficient mutants of Tannerella forsythensis
}

Correspondence

Yukitaka Murakami

yukimu@dpc.agu.ac.jp

Received 1 July 2006

Revised 11 November 2006

Accepted 16 November 2006
Junpei Sakakibara, ${ }^{1,2}$ Keiji Nagano, ${ }^{1} \dagger$ Yukitaka Murakami, ${ }^{1}$

Naoya Higuchi, ${ }^{3}$ Hiroshi Nakamura, ${ }^{3}$ Kazuo Shimozato ${ }^{2}$

and Fuminobu Yoshimura ${ }^{1}$

\author{
${ }^{1}$ Department of Microbiology, School of Dentistry, Aichi-Gakuin University, Nagoya, Aichi \\ 464-8650, Japan \\ ${ }^{2}$ Department of Oral and Maxillofacial Surgery II, School of Dentistry, Aichi-Gakuin University, \\ Nagoya, Aichi 464-8650, Japan \\ ${ }^{3}$ Department of Endodontics, School of Dentistry, Aichi-Gakuin University, Nagoya, Aichi \\ 464-8650, Japan
}

Tannerella forsythensis, one of the important pathogens in periodontal disease, has a typical surface layer (S-layer) consisting of regularly arrayed subunits outside the outer membrane. The S-layer in T. forsythensis is suggested to be associated with haemagglutinating activity, adhesion and invasion of host cells; however, its precise functions have been unknown. ORFs encoding the major S-layer proteins (230 and $270 \mathrm{kDa}$ ) of T. forsythensis ATCC 43037, tfs $A$ and tfsB, respectively, following the names in a recent report [Lee, S.-W., Sabet, M., Um, H. S., Yang, L., Kim, H. C. \& Zhu, W. (2006). Gene 371, 102-111] were determined. To verify the function of the S-layer proteins, three mutants with $t f s A, t f s B$, or both deleted were successfully constructed by a PCR-based overlapping method. S-layer proteins were completely lost in the double mutant. The single-deletion mutants appeared to lose one of the 230 and $270 \mathrm{kDa}$ proteins. Thin-section microscopy clearly revealed that the 230 and $270 \mathrm{kDa}$ proteins composed the S-layer. Although the S-layer proteins may be weakly related to haemagglutinating activity, these proteins were highly responsible for adherence to human gingival epithelial cells (Ca9-22) and KB cells. These results suggest that the S-layer proteins in T. forsythensis play an important role in the initiation stage of oral infection including periodontal disease.

\section{INTRODUCTION}

Tannerella forsythensis (formerly named Bacteroides forsythus) is a slow-growing, fastidious Gram-negative fusiform anaerobe that was originally isolated from advanced periodontal disease in the human oral cavity (Tanner et al., 1986; Sakamoto et al., 2002). T. forsythensis, Porphyromonas gingivalis and Treponema denticola form the so-called 'red complex', which is thought to be important in the pathogenesis and progression of destructive forms of periodontitis (Socransky et al., 1998; Holt \& Ebersol, 2005). Mixed infections by $P$. gingivalis and T. forsythensis showed a synergic effect on enhanced abscess formation in a murine model (Takemoto et al., 1997; Yoneda et al., 2001).

†Present address: Department of Molecular and Cell Biology, University of California, Berkeley, CA 94720-3202, USA.

Abbreviations: CAT, chloramphenicol acetyltransferase; CBB, Coomassie brilliant blue; $\mathrm{Cp}$, chloramphenicol; TIGR, The Institute for Genomic Research; TRITC, tetramethyl rhodamine isothiocyanate.
Recent studies have suggested an aetiological role of this organism in several forms of periodontal disease (Gersdorf et al., 1993; Takemoto et al., 1997; Haffajee et al., 1998; Yano-Higuchi et al., 2000), periradicular lesion (Gonçalves \& Mouton, 1999; Siqueira \& Rôças, 2003) and systemic disease (Noack et al., 2001; Hajishengallis et al., 2002).

Surface layers (S-layers) are regularly ordered proteins found as the outermost cell envelope components of many bacteria, representing approximately $10-15 \%(\mathrm{w} / \mathrm{w})$ of the total cellular protein of the bacterial cells (Boot \& Pouwels, 1996). The majority of S-layers are composed of a single protein or glycoprotein with a molecular mass of 40-200 kDa (Sleytr \& Messner, 1988; Sleytr et al., 1993; Sleytr \& Beveridge, 1999; Sára \& Sleytr, 2000). S-layers are considered to function as protective barriers, as molecular sieves, and in adhesion to cells, surface recognition, and maintenance of cell shape and envelope rigidity (Sleytr \& Messner, 1988; Sleytr et al., 1993; Sleytr \& Beveridge, 1999; Sára \& Sleytr, 2000). 
T. forsythensis has been reported to have an S-layer consisting of regularly arrayed subunits outside the outer membrane revealed by electron microscopy (Tanner et al., 1986; Kerosuo, 1988). Several studies reported that major high molecular mass proteins larger than $200 \mathrm{kDa}$ were characteristic of T. forsythensis (Kerosuo, 1988; Gersdorf et al., 1993). We have shown by immunoelectron microscopy that the S-layer is composed of 230 and $270 \mathrm{kDa}$ major proteins (Higuchi et al., 2000; Moriguchi et al., 2003). These S-layer proteins were shown to be specifically recognized by sera from patients with periodontitis (Yoneda et al., 2003). Recently, the S-layer protein was isolated and reported to be associated with haemagglutination, cell adhesion and invasion (Sabet et al., 2003).

In the 'red complex' bacteria, complete genome sequences of P. gingivalis and Treponema denticola have been determined (Nelson et al., 2003; Seshadri et al., 2004). A genome sequencing project for Tannerella forsythensis is also in progress at The Institute for Genomic Research (TIGR). From information on N-terminal and internal amino acid sequences of the 230 and $270 \mathrm{kDa}$ proteins, we attempted to identify S-layer protein genes ( $t f s A$ and $t f s B$, respectively, following the names in a recent paper by Lee et al., 2006) utilizing unfinished genome sequences, and then obtain deletion mutants to elucidate the function of the S-layer proteins. In this paper, we also describe the role of the Slayer proteins in haemagglutination and adherence to host cells, determined using S-layer gene deletion mutants.

\section{METHODS}

Bacterial strains, plasmids and growth conditions. The bacterial strains and plasmids used in this study are shown in Table 1. T. forsythensis ATCC 43037 was originally obtained from A. Tanner (The Forsyth Institute, Boston, MA, USA). All T. forsythensis were grown on Brucella HK agar (Kyokuto Pharmaceutical Industrial) supplemented with $5 \%(\mathrm{v} / \mathrm{v})$ laked rabbit blood, $2.5 \mu \mathrm{g}$ haemin $\mathrm{ml}^{-1}, 5 \mu \mathrm{g}$ menadione $\mathrm{ml}^{-1}, 0.1 \mathrm{mg}$ DTT $\mathrm{ml}^{-1}, 10 \mu \mathrm{g} N$-acetylmuramic acid $\mathrm{ml}^{-1}$ (Wyss, 1989; Braham \& Moncla, 1992) (blood agar) and appropriate antibiotics when necessary at $37^{\circ} \mathrm{C}$ for 7 days under anaerobic conditions $\left[10 \%(\mathrm{v} / \mathrm{v}) \mathrm{CO}_{2}, 10 \%(\mathrm{v} / \mathrm{v}) \mathrm{H}_{2}\right.$ and $80 \%(\mathrm{v} / \mathrm{v}) \mathrm{N}_{2}$ ]. A Zero Blunt TOPO PCR cloning kit, which included the plasmid vector pCR-Blunt II-TOPO, was purchased from Invitrogen, and Escherichia coli TOP10 carrying pCR-Blunt IITOPO was grown in Luria-Bertani medium supplemented with $25 \mu \mathrm{g}$ kanamycin $\mathrm{ml}^{-1}$. E. coli DH5 $\alpha$ carrying $\mathrm{pKD} 260$ was grown in Luria-Bertani medium supplemented with $25 \mu \mathrm{g}$ chloramphenicol (Cp) $\mathrm{ml}^{-1}$ as described previously (Ueda \& Yoshimura, 2003).

Construction of deletion mutants. We applied the PCR-based overlap extension method (Horton et al., 1993) described for deletion mutants in $P$. gingivalis (Nagano et al., 2005). DNA fragments that allowed the replacement of $t f_{s} A, t f_{s} B$, or both genes with the cat gene in the $T$. forsythensis chromosome were constructed. The primers and their annealing sites are shown in Table 2 and Fig. 1(a), respectively. Briefly, the cat gene, encoding chloramphenicol acetyltransferase (CAT), was amplified from the ATG start codon to the TAA stop codon with primers AGU-01 and AGU-02 to generate a $660 \mathrm{bp}$ product from pKD260. For construction of the $t f s A$-deletion cassette, the flanking sequence upstream of $t f_{S} A$ was amplified with primers AGU-71 and AGU-72, which have homology to the 5' end of the cat fragment. The flanking sequence downstream of $t f_{s} A$ was amplified with AGU-73 and AGU-74, which have homology to the $3^{\prime}$ end of the cat fragment. The cat, $t f_{s} A$-upstream and $t f_{s} A$-downstream fragments were used as templates for overlap extension PCR to generate a deletion cassette in which $t f_{s} A$ was replaced by cat.

The deletion cassettes of $t f_{s} B$ and $t f_{s} A / t f_{s} B$ were generated by similar procedures. Each deletion cassette created was ligated into pCR-Blunt II-TOPO and the resulting recombinant plasmids were transformed into competent cells of $E$. coli TOP10 according to the manufacturer's directions (Invitrogen). Constructs to be introduced for making mutants were sequenced before electroporation to rule out unintended base changes. Electroporation of $T$. forsythensis was performed essentially as described by Fletcher et al. (1995), except that the organism was grown on the plates for 7 days, scraped, washed and

Table 1. Bacterial strains and plasmids

\begin{tabular}{|c|c|c|}
\hline Strain or plasmid & Genotype or relevant characteristics ${ }^{\star}$ & Source or reference \\
\hline \multicolumn{3}{|l|}{ Tannerella forsythensis } \\
\hline ATCC 43037 & Wild-type, type strain ATCC $\dagger$ & \\
\hline$\Delta 230$ & $t f_{s} A$-deletion mutant from ATCC 43037, $\mathrm{Cp}^{\mathrm{r}}$ & This study \\
\hline$\Delta 270$ & $t f s B$-deletion mutant from ATCC 43037, $\mathrm{Cp}^{\mathrm{r}}$ & This study \\
\hline$\Delta 230-270$ & $t f_{s} A-$ and $t f_{s} B$-deletion mutant from ATCC 43037, $\mathrm{Cp}^{\mathrm{r}}$ & This study \\
\hline \multicolumn{3}{|l|}{ Escherichia coli } \\
\hline TOP10 & $\begin{array}{l}\text { As chemically competent cells, } \mathrm{F}^{-} \text {mcrA } \Delta(\text { mrr-hsdRMS-mcrBC }) \\
\phi 80 \text { lacZ } \Delta \mathrm{M} 15 \Delta \text { lacX74 recA1 deoR araD139 } \Delta(\text { ara-leu }) 7697 \text { galU } \\
\text { galK rpsL }\left(\mathrm{Str}^{\mathrm{r}}\right) \text { endA1 nupG }\end{array}$ & Invitrogen \\
\hline \multicolumn{3}{|c|}{ 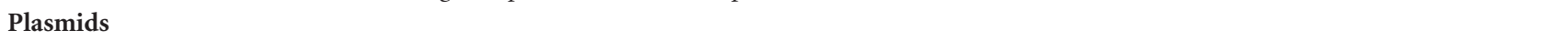 } \\
\hline pCR-Blunt II-TOPO & $\begin{array}{l}\text { Cloning vector, linearized with DNA topoisomerase I bound } \\
\text { to the } 3^{\prime} \text { end of each DNA strand, } \mathrm{Km}^{\mathrm{r}}\end{array}$ & Invitrogen \\
\hline pKD260 & $\begin{array}{l}\text { A derivative of pACYC184 with deletion of a } 1.1 \mathrm{kbp} \text { HincII } \\
\text { fragment, bearing cat gene, } \mathrm{Cp}^{\mathrm{r}}\end{array}$ & Nagano et al. (2005) \\
\hline
\end{tabular}

${ }^{\star} \mathrm{Cp}^{\mathrm{r}}$, chloramphenicol resistance; $\mathrm{Km}^{\mathrm{r}}$, kanamycin resistance.

$\dagger$ ATCC, American Type Culture Collection. 
Table 2. Primers

Primer-binding sites are shown in Fig. 1.

\begin{tabular}{|ll|}
\hline Primer & \multicolumn{1}{c|}{ Sequence $\left(\mathbf{5}^{\prime} \mathbf{- 3}^{\prime}\right)^{*}$} \\
\hline AGU-01 $\dagger$ & ATGGAGAAAAAAATCACTGGA \\
AGU-02 $\dagger$ & TTACGCCCCGCCCTGCCACTC \\
AGU-71 & CGTTCGGCGATCAATAAAGT \\
AGU-72 & CCAGTGATTTTTTCTCCATAATCAAATAATTAAATATTAATACTACGTAAAT \\
AGU-73 & GCAGGGCGGGGCGTAATAAGGTATTCATTAAATGGAAAGGAA \\
AGU-74 & GGTGTTTGAGCATTCGGATT \\
AGU-75 & TCCATGCAGGAGATACGTTG \\
AGU-76 & CCAGTGATTTTTTTCTCCATTTTTAATATTAATATTCAATTCGTATGGG \\
AGU-77 & GCAGGGCGGGGCGTAAATGTTGAAATAATCATTTGATTCAATATTAAG \\
AGU-78 & CCGAACATCGTGAGGAATCT \\
AGU-79 & TGATGAGCAAGAGCGTCTGT \\
AGU-83 & ACCGTTCGATAAGGATGTCG \\
Cat-39F & ATCCCAATGGCATCGTAAAG \\
Cat-486R & GGGCGAAGAAGTTGTCCATA \\
\hline
\end{tabular}

${ }^{\star}$ Underlines show overlapping regions of $5^{\prime}$ or $3^{\prime}$ end of cat.

$\dagger$ The same primers were used by Nagano et al. (2005).

suspended to obtain competent cells $\left(10^{11} \mathrm{cells}^{-1}\right)$. The plasmid constructs $(5 \mu \mathrm{g})$ were linearized by digestion with endonucleases $K p n \mathrm{I}$ and $\mathrm{XbaI}$ and introduced into electrocompetent cells of T. forsythensis $\left(10^{10}\right.$ cells). After $12 \mathrm{~h}$ anaerobic incubation in Trypticase soy broth (Becton Dickinson) supplemented with $2.5 \mathrm{mg}$ yeast extract $\mathrm{ml}^{-1}$, $2.5 \mu \mathrm{g}$ haemin $\mathrm{ml}^{-1}, 5 \mu \mathrm{g}$ menadione $\mathrm{ml}^{-1}, 0.1 \mathrm{mg} \mathrm{DTT} \mathrm{ml}^{-1}, 10 \mu \mathrm{g}$ $\mathrm{N}$-acetylmuramic acid $\mathrm{ml}^{-1}$ and $5 \%$ (v/v) Fildes extract (Oxoid), the pulsed cells were plated on blood agar supplemented with $12 \mu \mathrm{g} \mathrm{Cp}$ $\mathrm{ml}^{-1}$ and the plates were incubated anaerobically at $37^{\circ} \mathrm{C}$ for 7 days. Possible recombinants were verified by PCR.

Membrane preparation. Separation of whole envelopes from $T$. forsythensis strains was performed essentially as described previously (Murakami et al., 2002b, 2004). Briefly, bacterial cells were washed with $10 \mathrm{mM}$ HEPES/NaOH ( $\mathrm{pH} 7.4$ ) containing $0.15 \mathrm{M} \mathrm{NaCl}$ and then resuspended with $10 \mathrm{mM}$ HEPES/ $\mathrm{NaOH}$ ( $\mathrm{pH}$ 7.4) containing $0.1 \mathrm{mM} \mathrm{N}-\alpha$-p-tosyl-L-lysine chloromethyl ketone, $0.2 \mathrm{mM}$ PMSF and $0.1 \mathrm{mM}$ leupeptin (HEPES buffer). The cells were disrupted by sonication and the remaining undisrupted bacterial cells were removed by centrifugation at $1000 \mathrm{~g}$ for $10 \mathrm{~min}$. The envelope was collected as a pellet by centrifugation at $100000 \mathrm{~g}$ for $60 \mathrm{~min}$ at $4{ }^{\circ} \mathrm{C}$. The pellet was washed once by resuspending it in HEPES buffer and recentrifuged. The protein content of the membrane preparation was estimated by the method of Bradford (1976).

SDS-PAGE and Western blotting. SDS-PAGE was performed in a $1.0 \mathrm{~mm}$ thick $10 \%(\mathrm{w} / \mathrm{v})$ gel as described by Lugtenberg et al. (1975). The samples were usually solubilized in SDS buffer with 2mercaptoethanol at $100^{\circ} \mathrm{C}$ for $5 \mathrm{~min}$ (Hongo et al., 1999). The gels were stained with Coomassie brilliant blue R-250 (CBB). Western blotting was performed as described previously (Nishikawa \& Yoshimura, 2001). Proteins in the SDS-polyacrylamide gel were electrophoretically transferred onto a nitrocellulose membrane. The membrane was blocked with $1 \%(\mathrm{w} / \mathrm{v})$ BSA (fraction V) in Tris-buffered saline [TBS, $20 \mathrm{mM}$ Tris/ $\mathrm{HCl}$ ( $\mathrm{pH} 7.5$ ) containing $0.5 \mathrm{M}$ $\mathrm{NaCl}]$. Then the membrane was reacted with the antiserum followed by incubation with peroxidase-conjugated anti-rabbit IgG (MP
Biomedicals). After the membrane was washed, signals of the S-layer proteins were detected with $0.01 \%$ (w/v) 4-chloro-1-naphthol in TBS supplemented with hydrogen peroxide.

$\mathbf{N}$-terminal or internal amino acid sequence analysis. The Slayer proteins (230 and $270 \mathrm{kDa}$ ) from T. forsythensis ATCC 43037 were excised from CBB-stained SDS-PAGE gels. N-terminal amino acid sequences or internal amino acid sequences after digestion with Staphylococcus aureus V8 protease were analysed as described previously (Murakami et al., 2002b; Imai et al., 2005).

Preparation of specific antisera. Synthetic peptides derived from less-related amino acid sequences selected in the 230 and $270 \mathrm{kDa}$ proteins $\left(\mathrm{CR}^{510} \mathrm{LDPKNKKKDYSPVMGR}{ }^{526}\right.$ and $\mathrm{R}^{10}$ VKPYDNAKPTLKFK ${ }^{24} \mathrm{C}-\mathrm{NH}_{4}$, respectively, numbered from the $\mathrm{N}$-terminal amino acid estimated in ORFs of contig 5077) were purchased from the Peptide Institute. After peptide conjugation to thyroglobulin using $m$-maleimidobenzoyl- $N$-hydroxysuccinimide ester (Pierce Biotechnology), as described in the company's instructions, each peptide was emulsified with complete Freund's adjuvant and injected into rabbits subcutaneously four times at 2-week intervals. Specific antisera that reacted to both the 230 and $270 \mathrm{kDa}$ proteins of $T$. forsythensis were prepared as described previously (Higuchi et al., 2000).

Haemagglutination assay. Bacterial cells were washed once with $10 \mathrm{mM}$ phosphate buffer ( $\mathrm{pH} 7.0$ ) containing $0.15 \mathrm{M} \mathrm{NaCl}$ (PBS) and resuspended in the same buffer $\left(\mathrm{OD}_{600} 1.0\right)$. The haemagglutinating activity was determined at room temperature $\left(20-22{ }^{\circ} \mathrm{C}\right)$ in a round-bottomed microtitre plate (Murakami et al., 2002a). The bacterial sample $(50 \mu \mathrm{l})$ was diluted in twofold series in PBS, and $50 \mu \mathrm{l}$ of a $2 \%(\mathrm{v} / \mathrm{v})$ suspension of chicken or human erythrocytes was added. The mixtures were left standing for $90 \mathrm{~min}$. The titre was expressed as the reciprocal of the highest dilution showing positive agglutination.

For the screening of haemagglutination inhibition, $25 \mu \mathrm{l}$ of the cell suspension and $50 \mu \mathrm{l}$ of the erythrocyte suspension were sequentially added to $25 \mu \mathrm{l}$ of the solution containing the inhibitor to be tested (Murakami et al., 2002a). The concentration of the cell suspension was 


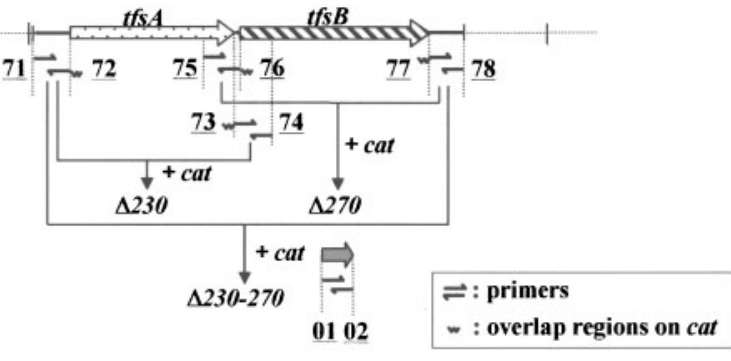

(b)
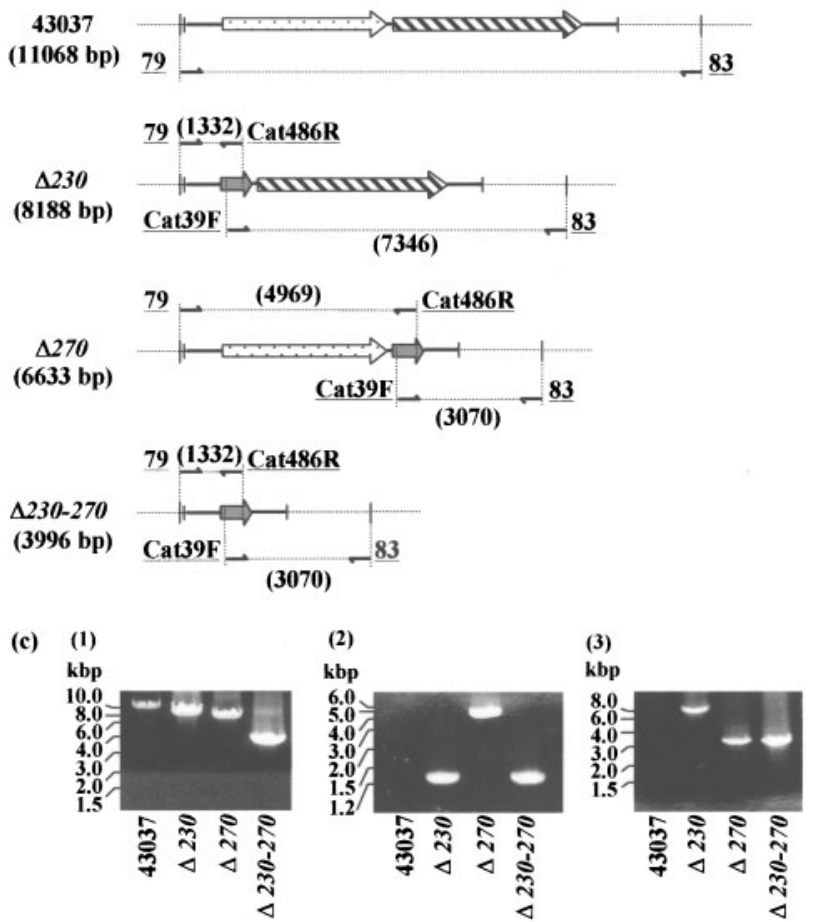

Fig. 1. Construction of $t f s A$ - and $t f s B$-deletion mutants from $T$. forsythensis ATCC 43037. (a) Gene arrangement in the chromosome and the procedure for construction of allele-exchange gene deletion, PCR primers and their annealing sites. (b) Predicted lengths of the PCR products in each genotype. Sizes of the DNA fragments are shown as base pairs in parentheses. (c) Verification of the mutants by gel electrophoresis of PCR products. (1) After amplification by PCR with primers AGU-79 and AGU-83, shown at the top of panel (b) as 79 and 83, respectively, the PCR products were subjected to electrophoresis. (2) After amplification by PCR with primers AGU-79 and Cat-486R. (3) After amplification by PCR with primers Cat-39F and AGU-83. Sequences of primers used are shown in Table 2. Dotted arrows, tfs $A$ and its transcriptional direction; diagonally striped arrows, tfs $B$; grey arrows, cat; small arrows, primers and directions for chain elongation; wavy line, overlap regions on cat; underlined numbers, simplified primer designation (see Table 1 for details).

adjusted to twice the minimal concentration at which distinct haemagglutination occurred. Haemagglutination was recorded after $90 \mathrm{~min}$. The reaction mixture that did not contain the substances was used as a positive control of haemagglutination.
Cell cultures. Cell lines Ca9-22 (JCRB0625, epithelial cell-like gingival carcinoma cell line) and KB (JCRB9027) were obtained from Health Science Research Resources Bank, Osaka, Japan. KB cells are now known to be HeLa cells (Masters, 2002). The cells were grown at $37^{\circ} \mathrm{C}$ for $2-3$ days in $5 \%(\mathrm{v} / \mathrm{v}) \mathrm{CO}_{2}$ in Dulbecco's Modified Eagle Medium (DMEM; Invitrogen) supplemented with $10 \%(\mathrm{v} / \mathrm{v})$ fetal calf serum (Invitrogen).

Bacterial adherence assay by confocal laser scanning microscopy. Ca9-22 and KB cells were subcultured into Lab-Tek IIchamber slides (Nalge Nunc International) and grown for $24 \mathrm{~h}$ before adherence study. Ca9-22 or KB cells grown to near confluence of $10^{5}$ cells per well were washed with PBS to remove unattached cells from the chamber slides. Then T. forsythensis cells, which were washed with PBS and resuspended in DMEM at a con-

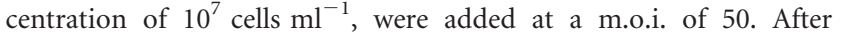
incubation under $5 \% \mathrm{CO}_{2}$ at $37^{\circ} \mathrm{C}$ for $3 \mathrm{~h}$, chamber slides were washed three times with PBS, each followed by gentle shaking for $15 \mathrm{~min}$ at room temperature, and fixed with $4 \%(\mathrm{v} / \mathrm{v})$ paraformaldehyde at $4{ }^{\circ} \mathrm{C}$ overnight. After the fixed cells had been washed three times with TBS, they were permeabilized with TBS containing $0.05 \%(\mathrm{v} / \mathrm{v})$ Triton $\mathrm{X}-100$ at $37^{\circ} \mathrm{C}$ for $30 \mathrm{~min}$. They were washed again and then blocked with TBS containing $1 \%(\mathrm{w} / \mathrm{v})$ BSA at $37^{\circ} \mathrm{C}$ for $30 \mathrm{~min}$. Bacterial cells on chamber slides were labelled with antiT. forsythensis whole-cell antserum (1:1000 dilution) for $60 \mathrm{~min}$ at $37^{\circ} \mathrm{C}$ and washed five times with TBS containing $0.05 \%$ Tween 20 . Then bacterial cells were incubated with the FITC-conjugated goat IgG fraction to the rabbit IgG $\mathrm{F}\left(\mathrm{ab}^{\prime}\right)_{2}$ secondary antibody $(1: 1000$ dilution, ICN Pharmaceuticals). Actin filaments in Ca9-22 or KB cells were simultaneously stained with tetramethylrhodamine isothiocyanate (TRITC)-labelled phalloidin $\left(1 \mu \mathrm{g} \mathrm{ml}^{-1}\right.$, Sigma-Aldrich) for $60 \mathrm{~min}$ at $37^{\circ} \mathrm{C}$ in the dark. After five washes with TBS containing $0.05 \%(\mathrm{v} / \mathrm{v})$ Tween 20, chamber slides were mounted onto a slide containing $10 \mu \mathrm{l}$ SlowFade Light Antifade (Invitrogen). Immunostained slides were kept in the dark until analysed. Adherent bacteria on the cell surfaces were examined by the laser scanning system Radience 2100 (Bio-Rad) mounted on an Axiovert 200 inverted microscope (Carl Zeiss) equipped with a $\times 63$ objective.

Quantitative bacterial adherence assay. For quantitative bacterial adherence assay, $\mathrm{Ca} 9-22$ and $\mathrm{KB}$ cells were subcultured into 24-well culture plates (Corning) and grown to near confluence of $5 \times 10^{5}$ cells per well for $24 \mathrm{~h}$. The cells were washed with PBS to remove unattached cells from the wells. Then $T$. forsythensis cell suspension at a concentration of $10^{7}$ cells $\mathrm{ml}^{-1}$ was added at a m.o.i. of 100. After incubation under $5 \% \mathrm{CO}_{2}$ at $37^{\circ} \mathrm{C}$ for $3 \mathrm{~h}$, non-adherent bacteria were removed by washing three times with PBS. After the cells had been disrupted by the addition of sterile distilled water $(100 \mu \mathrm{l})$ and incubated at $37^{\circ} \mathrm{C}$ for $10 \mathrm{~min}$, serial dilutions of the disrupted mixture were plated on blood agar plates and incubated anaerobically at $37^{\circ} \mathrm{C}$ for 7 days. The numbers of viable adherent bacteria were determined by plating followed by counting the colonies that appeared. All assays were performed in triplicate.

Electron microscopy. T. forsythensis whole cells were fixed at $4{ }^{\circ} \mathrm{C}$ for $2 \mathrm{~h}$ with $4 \%(\mathrm{w} / \mathrm{v})$ paraformaldehyde and $5 \%(\mathrm{v} / \mathrm{v})$ glutaraldehyde in $0.1 \mathrm{M}$ cacodylate buffer. Samples were washed and postfixed with $4 \%(\mathrm{w} / \mathrm{v})$ osmium tetraoxide for $90 \mathrm{~min}$ and then $0.5 \%$ $(\mathrm{w} / \mathrm{v})$ uranyl acetate for $20 \mathrm{~min}$. The fixed cells were dehydrated in ethanol and embedded in L-R white resin (London Resin). Ultrathin sections were stained with uranyl acetate and lead citrate. Cells were also negatively stained on carbon-coated grids with $2 \%(\mathrm{w} / \mathrm{v})$ uranyl acetate. Stained samples were observed using a transmission electron microscope (JEM-1210, JEOL).

Antimicrobial susceptibility. All antibiotics (chloramphenicol, ampicillin, tetracycline, cephalothin, erythromycin, ofloxacin, bacitracin and vancomycin) were purchased from Sigma-Aldrich. Assays 
were performed essentially as described previously (Nagano et al., 2005). MIC was evaluated by agar dilution assay, as recommended by the National Committee for Clinical Laboratory Standards (1997). Briefly, serial dilutions of the corresponding antibiotics were added to blood agars. After precultured bacteria were grown on blood agar, and washed bacterial suspension $(2 \mu \mathrm{l})$ was spotted on the antibiotic-containing agar. After 7 days of anaerobic incubation, the susceptibility breakpoints were determined.

\section{RESULTS}

\section{Identification of S-layer protein genes}

Partial amino acid sequences of electrophoretically purified S-layer proteins were identified (Table 3). The sequences were compared with the unfinished genome of $T$. forsythensis obtained from the TIGR website (http:// www.tigr.org) using the BLAST program (http:// www.ncbi.nlm.nih.gov/blast/), and two ORFs encoding the S-layer proteins were found. Two genes, $t f_{s} A$ encoding a $230 \mathrm{kDa}$ protein and $t f_{s} B$ encoding a $270 \mathrm{kDa}$ protein, were tandemly located from $2833655 \mathrm{bp}$ to $2837191 \mathrm{bp}$ and 2837292 bp to 2841383 bp in contig 5077, respectively. In the case of tsfA, the stop codon (TAG) was found at 2835326 bp to 2835328 bp in the unfinished genome of $T$. forsythensis. Since the internal amino acid sequences $(230 \mathrm{~K}$ fragments 1, 2 and 3 in Table 3), determined using partial digests of pure $230 \mathrm{kDa}$ protein, were distributed before and after the stop codon at the corresponding DNA region in contig 5077, we noticed that the stop codon was incorrectly assigned due to the incomplete sequence. The calculated molecular masses of TsfA and TsfB based on the ORFs are about $120 \mathrm{kDa}$ and $140 \mathrm{kDa}$, respectively, much smaller than the apparent molecular masses of $230 \mathrm{kDa}$ and $270 \mathrm{kDa}$, respectively. Therefore, we speculate that the S-layer proteins might be post-translationally modified.

\section{Construction of deletion mutants}

Construction of three deletion mutants from T. forsythensis wild-type strain ATCC 43037 was performed by the PCRbased overlap extension method, in which ORFs for $t f_{S} A$ and/or $t f s B$ were deleted and replaced by cat, the gene encoding CAT. The overall design for construction of the mutants is shown in Fig. 1. Transformants were detected at a frequency of $10^{-7}$ to $10^{-6}$ per pulsed cell, and the number of transformants obtained was 200-2000 per $\mu$ g plasmid DNA. To confirm the replacement of ORFs for $270(t f s A)$ and/or $230 \mathrm{kDa}$ proteins $(t f s B)$ by cat, the cloning sites were amplified by PCR with the use of chromosomes from each mutant as a template with several primers as shown in Fig. 1(b). All the amplified products showed the predicted fragments (Fig. 1c). All the constructed mutants showed no difference from the parent strain in colony morphology or growth on blood agar plates.

\section{SDS-PAGE and Western blotting}

Bacterial envelopes were subjected to SDS-PAGE. The parent strain showed major 230 and $270 \mathrm{kDa}$ protein bands, whereas the single mutants had lost one of these bands and the double mutant both bands (Fig. 2). Specific antisera to the 230 and $270 \mathrm{kDa}$ proteins, prepared using conjugated synthetic peptides as antigens, successfully discriminated the two proteins by Western blot analysis. Anti-230 kDa protein antiserum detected the $230 \mathrm{kDa}$ protein in the parent and $\Delta 270$, and anti- $270 \mathrm{kDa}$ protein antiserum exclusively detected the $270 \mathrm{kDa}$ protein in the parent and $\Delta 230$, as predicted. No immunoreactive bands appeared in the double mutant, confirming that the 230 and $270 \mathrm{kDa}$ proteins were products of $t f s A$ and $t f s B$, respectively. The single-deletion mutants appeared to have lost the corresponding 230 or $270 \mathrm{kDa}$ protein. Immunoreactive bands at around $100 \mathrm{kDa}$ in Fig. 2(c) were derived from the $270 \mathrm{kDa}$ protein because none of these bands was detected in $\Delta 270$ and $\Delta 230-270$.

\section{Electron microscopy}

Thin-section microscopy revealed that the parent had a regularly arrayed structure at the outermost cell surface. In contrast, the double mutant had completely lost the structure, and the single mutants retained smaller amounts of it (Fig. 3). These results clearly indicated that the S-layer

Table 3. N-terminal and internal amino acid sequences of the S-layer proteins

\begin{tabular}{|lclc|}
\hline S-layer protein $^{*}$ & Apparent mol. mass (kDa) & \multicolumn{1}{c|}{ Amino acid sequence } & Nucleotide position in contig 5077 $\dagger$ (bp) \\
\hline $230 \mathrm{~K}$ & 230 & RPFYGDAVKYLPEGMGKGAY & $2833727-2833786$ \\
$230 \mathrm{~K}$ fragment 1 & 100 & YYLVLDDNGRYGYTPEVI & $2835689-2835742$ \\
$230 \mathrm{~K}$ fragment 2 & 25 & GSSISKIHLINREFDDIRI & $2835074-2835130$ \\
$230 \mathrm{~K}$ fragment 3 & 20 & FSQKVSAGQVNPFEQPLMAE & $2834414-2834473$ \\
$270 \mathrm{~K}$ & 270 & Unidentified & $2838279-2838335$ \\
$270 \mathrm{~K}$ fragment 1 & 200 & VEYLDGISPVTAMLIDSSA & $2837391-2837450$ \\
$270 \mathrm{~K}$ fragment 2 & 40 & QQQLRVKPYDNAKPTLKFKE & $2837391-2837450$ \\
$270 \mathrm{~K}$ fragment 3 & 25 & QQQLRVKPYDNAKPTLKFKE & \\
\hline
\end{tabular}

*Fragments were obtained from partial digestion of the S-layer protein with Staphylococcus aureus V8 protease.

$\dagger$ Preliminary sequence data of contig 5077 in the T. forsythensis genome were obtained from TIGR website at http://www.tigr.org. 


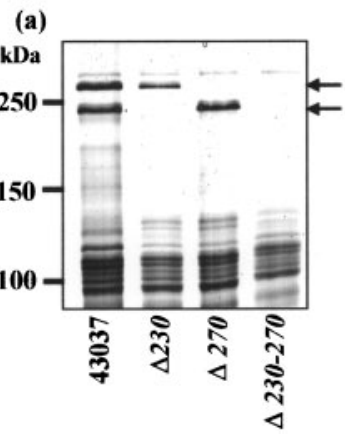

(b)

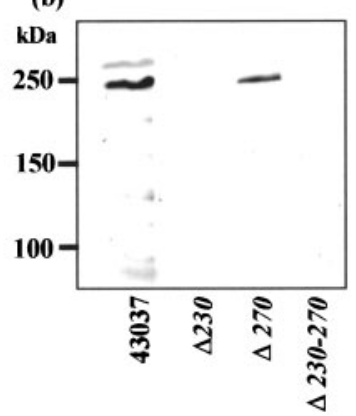

(c)

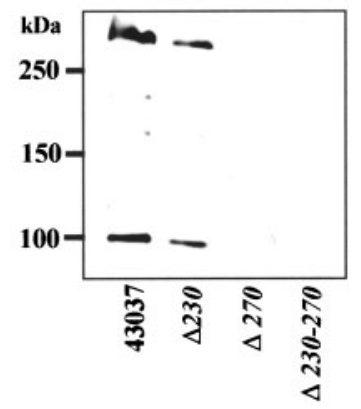

Fig. 2. Typical protein patterns and Western blots of envelope fractions. Bacterial envelopes were denatured in SDS with 2-mercaptoethanol at $100^{\circ} \mathrm{C}$ for $5 \mathrm{~min}$ and then loaded onto SDS-polyacrylamide gels. The gels were stained with CBB (a) and subjected to Western blot analysis with anti230 (b) or $-270 \mathrm{kDa}$ protein-specific serum (c). Fifty micrograms of each protein was applied to each lane of the gels. See Methods for details of the sera. was composed of the 230 and $270 \mathrm{kDa}$ proteins. Even after deletion of the S-layer genes, the fusiform shape was not changed. Negative staining microscopy also showed that the S-layer-deficient mutants maintained almost the same cell shape as the wild-type (data not shown).

\section{Haemagglutinating activity}

Compared to the parent, $\Delta 230$ and $\Delta 270$ showed two- to fourfold lower haemagglutination, whereas the double mutant retained almost the same activity (Table 4). Similar results were obtained when erythrocytes from different volunteers or chicken were used, and experiments were independently repeated. Haemagglutination inhibition assay using specific antibodies to the 270 and/or $230 \mathrm{kDa}$ proteins revealed that the contribution of the S-layer proteins to haemagglutination was much less, because inhibition was almost the same as with pre-immune control serum (data not shown).

\section{Bacterial adhesion to host cells}

Bacteria located at the surface of host cells were observed by confocal laser scanning microscopy. T. forsythensis were labelled with FITC (green), and skeletal actin in the host cell was stained with TRITC-phalloidin (red). The parent

\section{(a) 43037}

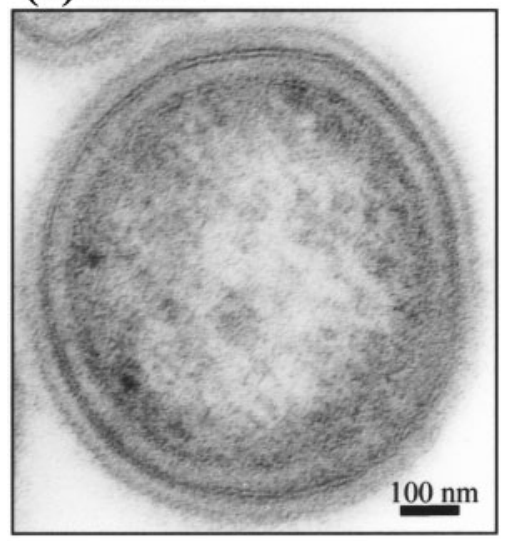

(c) $\Delta 270$

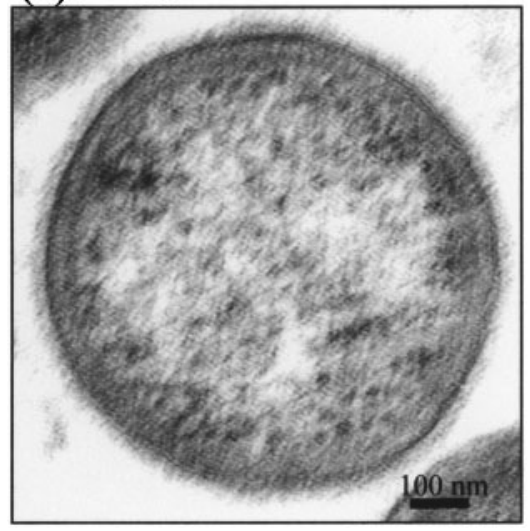

(b) $\Delta 230$

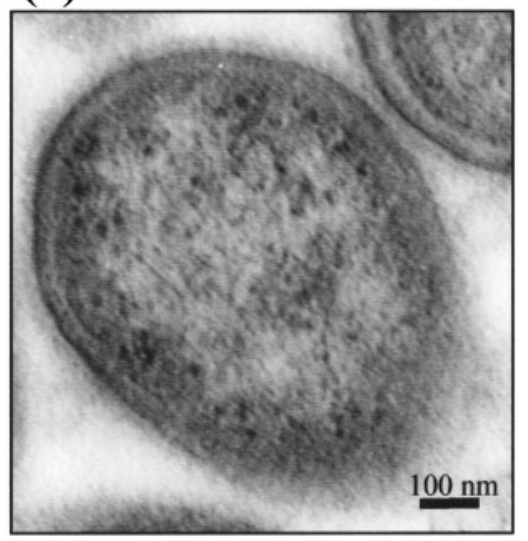

(d) $\Delta 230-270$

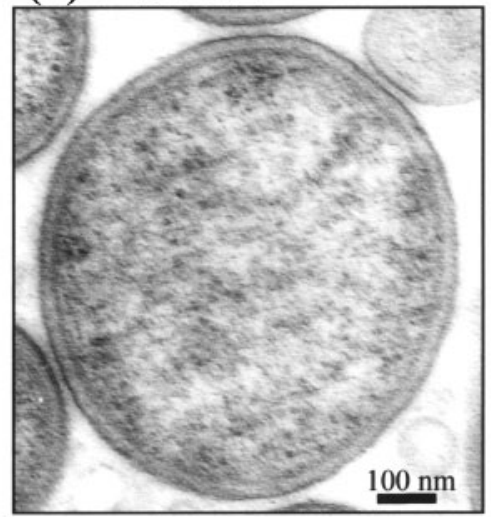

Fig. 3. Electron micrographs of the thinsectioned T. forsythensis cells. The cells were stained with uranyl acetate and lead citrate. Micrographs in which spindle-shaped cells were cross-sectioned are selected for S-layer observation. (a) The parent ATCC 43037; (b) $\Delta 230$; (c) $\Delta 270$; (d) $\Delta 230-270$. Bars, $100 \mathrm{~nm}$. 
Table 4. Comparison of haemagglutination of $T$. forsythensis wild-type and the S-layer-deficient mutants

\begin{tabular}{|lcc|}
\hline \multirow{2}{*}{ Strain } & \multicolumn{2}{c|}{ Haemagglutinating titre } \\
\cline { 2 - 3 } & Human erythrocytes & Chicken erythrocytes \\
\hline ATCC 43037 & 16 & 16 \\
$\Delta 230$ & 8 & 4 \\
$\Delta 270$ & 4 & 2 \\
$\Delta 230-270$ & 16 & 8 \\
\hline
\end{tabular}

adhered to Ca9-22 cells in a dispersed fashion, without forming large aggregates, whereas marked decreases of bacterial adherence were observed in the three mutants (Fig. 4a). Since there was no distinctive difference among observed fields, a set of representative images of the parent and the mutants is shown. Similarly, the parent, but not the mutants, had the ability to adhere to KB cells (Fig. 4b); however, careful staining procedures were necessary to avoid detaching $\mathrm{KB}$ cells from the chamber slide surface.

Quantitative adhesion assay by colony counting clearly revealed that adherence of T. forsythensis to both Ca9-22 and $\mathrm{KB}$ cells was significantly reduced when either of the S-layer proteins was deleted (Fig. 5). Thus, the observations by confocal laser microscopy were quantitatively confirmed by viable-cell counting data.

\section{Antimicrobial susceptibility}

The MIC of Cp for T. forsythensis ATCC 43037 was $3 \mu \mathrm{g} \mathrm{ml}^{-1}$, while those for the three mutants were $>25 \mu \mathrm{g} \mathrm{ml}^{-1}$, probably due to the strong CAT expression (Table 5). Strong CAT activity was detected only in the mutants where cat had been introduced (data not shown). The mutants showed fourfold lower MICs to vancomycin $\left(0.78 \mu \mathrm{g} \mathrm{ml}^{-1}\right)$ than the wild-type $\left(3.13 \mu \mathrm{g} \mathrm{ml}^{-1}\right)$. However, MICs of other antibiotics (chloramphenicol, ampicillin, tetracycline, cephalothin, erythromycin, ofloxacin and bacitracin) did not differ significantly between the parent and the three mutants. Most MIC tests were repeated three times.

\section{DISCUSSION}

T. forsythensis is an important bacterium in periodontitis. Most studies have been focused on detection of this bacterium from periodontal disease; relatively few have dealt with potential virulence factors at the molecular level. Several T. forsythensis antigens have been cloned (Saito et al., 1997; Sharma et al., 1998, 2005; Hughes et al., 2003; Ishikura et al., 2003; Inagaki et al., 2005). Honma et al. (2001) reported the generation of specific gene knockout mutants of $T$. forsythensis for the first time using a suicide plasmid. We followed their procedure to obtain deletion mutants; however, no mutants were obtained. Therefore, we employed PCR-based overlapping methods, which were successful in producing deletion mutants in $P$. gingivalis (a) Ca9-22 cells

\section{7}

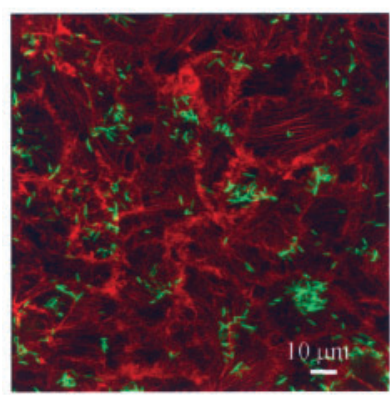

$\Delta 270$

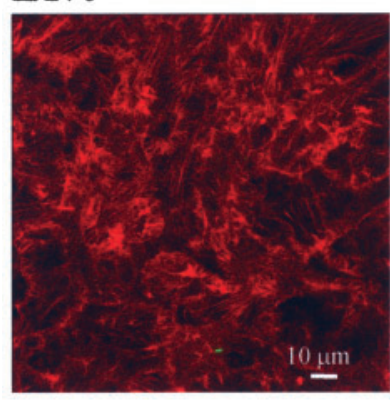

(b) KB cells

43037

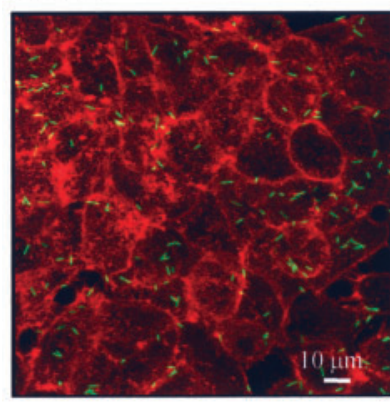

$\Delta 270$

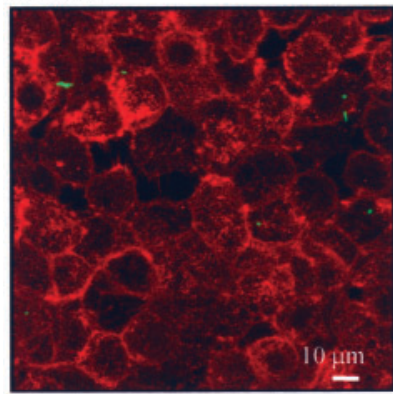

$\Delta 230$

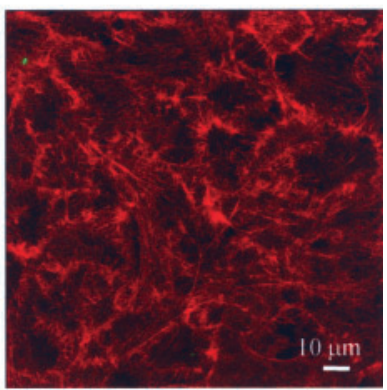

$\Delta 230-270$

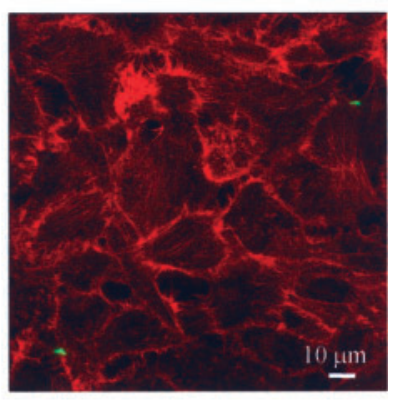

$\Delta 230$

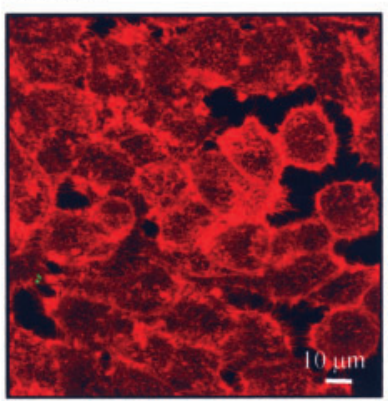

$\Delta 230-270$

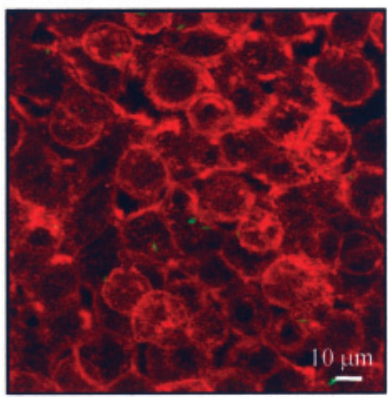

Fig. 4. Confocal laser scanning photomicrographs showing adherence of $T$. forsythensis to Ca9-22 and KB cells. The bacteria were stained with FITC (green) and the cytoskeleton of the epithelial cells was visualized with TRITC (red). (a) Ca9-22 cells; (b) KB cells. Bars, $10 \mu \mathrm{m}$. 


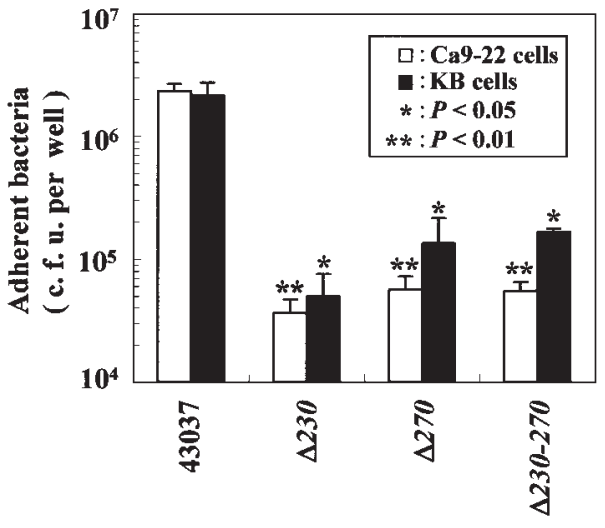

Fig. 5. Quantitative adhesion assay of $T$. forsythensis to Ca922 and KB cells. T. forsythensis suspensions were added to monolayers of the epithelial cells in 24-well plates at a m.o.i. of 100 and allowed to adhere for $3 \mathrm{~h}$. After the monolayers had been washed with PBS three times, the cells were lysed with distilled water. The numbers of viable, adherent $T$. forsythensis cells were determined by plating followed by counting the colonies that appeared. Values represent the means \pm SD of the triplicate determinations from a typical experiment.

(Nagano et al., 2005). The gene to be deleted by this method should at least have a strong promoter in front of it to express the cat gene adequately. Since the S-layer proteins were expressed in a large amount in T. forsythensis, the cat gene would be strongly transcribed by the promoter of $t f s A$ and $t f_{s} B$. Consequently, Cp-resistant mutants could be selected. To the best of our knowledge, this is the first report of gene deletion being systematically performed in $T$. forsythensis studies. This method would be useful to determine the functions of other putative virulence factors in T. forsythensis.

Very recently, Lee et al. (2006) reported S-layer genes from T. forsythensis. Sequences of the genes reported (accession no. AY23857) completely matched those we analysed. Although we initially speculated that the S-layer proteins

Table 5. MICs of various antibiotics for $T$. forsythensis wild-type and the S-layer-deficient mutants

Abbreviations: CP, chloramphenicol; ABPC, ampicillin; TC, tetracycline; CFX, cephalothin; EM, erythromycin; OFLX, ofloxacin; $\mathrm{BC}$, bacitracin; VCM, vancomycin.

\begin{tabular}{|lccccccccc|}
\hline \multirow{2}{*}{ Strain } & \multicolumn{8}{c|}{ MIC $\left(\boldsymbol{\mu \mathrm { g } \mathrm { ml } ^ { - \mathbf { 1 } } )}\right.$} \\
\cline { 2 - 9 } & CP & ABPC & TC & CFX & EM & OFLX & BC & VCM \\
\hline ATCC 43037 & 3.13 & 0.78 & 0.78 & 0.78 & 1.56 & 3.13 & 25 & 3.13 \\
$\Delta 230$ & $>25$ & 0.78 & 0.78 & 0.78 & 1.56 & 3.13 & 25 & 0.78 \\
$\Delta 270$ & $>25$ & 0.78 & 0.78 & 0.78 & 1.56 & 3.13 & 25 & 0.78 \\
$\Delta 230-270$ & $>25$ & 0.78 & 0.78 & 0.78 & 1.56 & 3.13 & 25 & 0.78 \\
& & & & & & & & \\
\hline
\end{tabular}

(230 and $270 \mathrm{kDa}$ ) might be single gene products due to cross-immunoreactivity in a previous paper (Higuchi et al., 2000), these proteins turned out to be encoded by two genes, $t f_{s} A$ and $t f_{s} B$, when the unfinished genome sequence became available soon after. $t f_{s} A$ and $t f_{s} B$ form an operon structure according to Northern blot and RT-PCR analyses (Lee et al., 2006). Both gene products, which are reported to exhibit $24 \%$ similarity to each other (Lee et al., 2006), seemed to be expressed in almost the same amount, judged from intensities of the protein bands in CBB-stained gels (Higuchi et al., 2000). It was hypothesized that S-layer genes of $T$. forsythensis might belong to a novel class, since two large proteins were encoded by two separate genes (Lee et al., 2006). Generally, S-layers are composed of a single protein or glycopotein subunit (Sára \& Sleytr, 2000). Although several lactobacilli possess multiple S-layer protein genes, these genes can be differentially or simultaneously expressed depending on growth conditions (ÅvallJääskeläinen \& Palva, 2005). Signal sequences for TfsA and TfsB (230 and $270 \mathrm{kDa}$, respectively) were estimated as having 22 and 28 amino acids (although unintentionally depicted as 19 and 30 amino acids, respectively, in the figures), respectively, in a previous report (Lee et al., 2006). The signal peptide for $\mathrm{Tfs} A$ was assigned as MNKKVFTLLAASLMLFMTAFMADA (24 amino acids) because we successfully determined the N-terminal sequence of the $230 \mathrm{kDa}$ protein (Table 3). However, the $\mathrm{N}$-terminal sequence of TfsB was unidentified, presumably because of N-terminal blockage. The predicted N-terminal amino acid of the mature $\mathrm{TfsB}$ protein is presumably glutamine, 5 amino acids ahead of the N-terminal amino acid of the two digested peptides $(270 \mathrm{~K}$ fragments 2 and 3 in Table 3), since it is known to be convertible to pyroglutamic acid, an undetected amino acid derivative in the sequence reaction (Murakami et al., 2002b). As another possibility, glycosylation might cause N-terminal blockage. Therefore, we estimated here that the signal sequence was MIMIMNKKIFTLLAGAFMGFAAVSSVTA (28 amino acids). We have shown by electron microscopy using the deletion mutants that the 230 and $270 \mathrm{kDa}$ proteins compose the S-layer; however, the precise molecular arrangement of these proteins in the S-layer remains unclear. Lee et al. (2006) also reported that the Slayer proteins from $T$. forsythensis were glycoproteins. We confirmed this using a commercial glycoprotein staining kit after SDS-PAGE (data not shown). However, the exact contents and compositions of sugars in the S-layer proteins are unknown.

Previous studies indicated that T. forsythensis cells (Munemasa et al., 2000), especially the S-layer (Sabet et al., 2003), had haemagglutinating and adherence activities. We therefore examined whether the S-layer proteins on the $T$. forsythensis cell surface might contain haemagglutinin, using S-layer protein deletion mutants. Our results indicated that lack of the S-layer had a minor effect on haemagglutination. Moreover, haemagglutination inhibition by the S-layer-specific antisera raised against the 
230 and/or $270 \mathrm{kDa}$ proteins was almost the same as that by the control pre-immune serum. Thus the S-layer seemed to have a marginal association with the haemagglutinating activity. Since thin-section microscopy revealed that the cell surfaces of the single mutants $(\Delta 230$ and $\Delta 270)$ were partially covered with substances like the S-layer, an abnormal state of the cell surface could hinder haemagglutinating activity. On the other hand, in the double mutant ( $\Delta 230-270)$, which lacked the S-layer completely, the putative haemagglutinin might be fully exposed and function. We have previously reported $\mathrm{N}$-acetylneuraminyllactose-sensitive haemagglutinin on the envelope, although its gene has not been identified yet (Murakami et al., 2002a). We could not find any reliable report on other bacteria whose S-layer protein had haemagglutinating activity.

In contrast, the S-layer proteins in T. forsythensis were clearly responsible for adhesion to the host cells. The S-layer protein-deletion mutants almost completely lost adherence. Although only a few bacteria were internalized into the host cells even in the wild-type strain (data not shown), we speculated that invasion of the host cells, which may occur after adhesion, would be lower in the deletion mutants. It has been reported that Lactobacillus S-layers are involved in mediating adhesion to different host tissues (ÅvallJääskeläinen \& Palva, 2005), whereas the S-layer from Campylobacter rectus had little effect on adhesion to HEp-2 epithelial cells (Wang et al., 2000). To examine the pathogenicity of the S-layer in T. forsythensis, a murine abscess lesion model, as described essentially for $P$. gingivalis (Kumagai et al., 2001), was used; however, the parent and all three mutants caused abscesses to similar degrees and we could not detect any difference between the parent and the mutant strains (data not shown). Mixed infection with other bacteria in the murine abscess model may be needed to detect differences of virulence among them (Yoneda et al., 2001).

The S-layer is an important interface between the bacterial cell and its environment (Sleytr et al., 1993). We used several representative antibiotics to examine whether the S-layer might contribute to antimicrobial susceptibility. MICs for the wild-type were similar to those described by Takemoto et al. (1997). Most of the MICs for the mutants were not different from that for the wild-type. The mutants showed higher MICs to Cp because of cat gene expression. On the other hand, MICs to vancomycin were lower in the mutants. The reason is unclear; however, S-layers in prokaryotes are considered to function as molecular sieves and as ion traps (Sleytr \& Messner, 1988; Sleytr et al., 1993; Sleytr \& Beveridge, 1999; Sára \& Sleytr, 2000). Regarding another function, the T. forsythensis S-layer proteins did not play a role in cell shape determination and maintenance as judged from electron microscopy. Not only thin-sectioned cells but also negatively stained cells showed similar cell shapes for wild-type and the S-layer-deficient strains. Other possible functions of S-layer proteins, molecules related to S-layer synthesis, and molecules for anchoring S-layer proteins to the outer membrane will be elucidated in the near future.

In this study, we have shown a systematic method for construction of gene-deletion mutants in T. forsythensis. Although $T$. forsythensis S-layer proteins seemed to have a marginal relationship to haemagglutinating activity, these proteins were responsible for adhesion to Ca9-22 gingival epithelial cells and KB cells. In conclusion, S-layer proteins in $T$. forsythensis may play an important role in the early stage of oral infections, including periodontal disease.

\section{ADDENDUM}

After the completion of this study, we learned that a similar approach was taken by Lee et al. (2006).

\section{ACKNOWLEDGEMENTS}

Part of this work is taken from the thesis submitted by Junpei Sakakibara to the Graduate Faculty, School of Dentistry, Aichi-Gakuin University, in partial fulfilment of the requirements for his doctoral degree. We thank T. Hirose and the late Y. Abe (Center for Instrumental Analysis, Hokkaido University) for analysing amino acid sequences. Preliminary sequence data were obtained from the TIGR website at http://www.tigr.org. This work was supported by Grants-in-Aid for Scientific Research from the Japan Society for the Promotion of Science (15591957 to F. Y. and 15591958 to Y.M.) and the AGU High-Tech Research Center Project for Private Universities: matching fund subsidy from MEXT (the Ministry of Education, Culture, Sports, Science and Technology, Japan), 2003-2007.

\section{REFERENCES}

Åvall-Jääskeläinen, S. \& Palva, A. (2005). Lactobacillus surface layers and their applications. FEMS Microbiol Rev 29, 511-529.

Boot, H. T. \& Pouwels, P. H. (1996). Expression, secretion and antigenic variation of bacterial S-layer proteins. Mol Microbiol 21, 1117-1123.

Bradford, M. M. (1976). A rapid and sensitive method for the quantitation of microgram quantities of protein utilizing the principle of protein-dye binding. Anal Biochem 72, 248-254.

Braham, P. H. \& Moncla, B. J. (1992). Rapid presumptive identification and further characterization of Bacteroides forsythus. J Clin Microbiol 30, 649-654.

Fletcher, H. M., Schenkein, H. A., Morgan, R. M., Bailey, K. A., Berry, C. R. \& Macrina, F. L. (1995). Virulence of a Porphyromonas gingivalis W83 mutant defective in the prtH gene. Infect Immun 63, 1521-1528.

Gersdorf, H., Meissner, A., Pelz, K., Krekeler, G. \& Göbel, U. B. (1993). Identification of Bacteroides forsythus in subgingival plaque from patients with advanced periodontitis. J Clin Microbiol 31, 941-946.

Gonçalves, R. B. \& Mouton, C. (1999). Molecular detection of Bacteroides forsythus in infected root canals. J Endod 25, 336-340.

Haffajee, A. D., Cugini, M. A., Tanner, A., Pollack, R. P., Smith, C., Kent, R. L., Jr \& Socransky, S. S. (1998). Subgingival microbiota in healthy, well-maintained elder and periodontitis subjects. J Clin Periodontol 25, 346-353. 
Hajishengallis, G., Sharma, A., Russell, M. W. \& Genco, R. J. (2002). Interactions of oral pathogens with Toll-like receptors: possible role in atherosclerosis. Ann Periodontol 7, 72-78.

Higuchi, N., Murakami, Y., Moriguchi, K., Ohno, N., Nakamura, H. \& Yoshimura, F. (2000). Localization of major, high molecular weight proteins in Bacteroides forsythus. Microbiol Immunol 44, 777-780.

Holt, S. C. \& Ebersol, J. L. (2005). Porphyromonas gingivalis, Treponema denticola, and Tannerella forsythia: the "red complex", a prototype polybacterial pathogenic consortium in periodontitis. Periodontol 2000 38, 72-122.

Hongo, H., Osano, E., Ozeki, M., Onoe, T., Watanabe, K., Honda, O., Tani, H., Nakamura, H. \& Yoshimura, F. (1999). Characterization of an outer membrane protein gene, pgmA, and its gene product from Porphyromonas gingivalis. Microbiol Immunol 43, 937-946.

Honma, K., Kuramitsu, H. K., Genco, R. J. \& Sharma, A. (2001). Development of a gene inactivation system for Bacteroides forsythus: construction and characterization of a BspA mutant. Infect Immun 69, 4686-4690.

Horton, R. M., Ho, S. N., Pullen, J. K., Hunt, H. D., Cai, Z. \& Pease, L. R. (1993). Gene splicing by overlap extension. Methods Enzymol 217, 270-279.

Hughes, C. V., Malki, G., Loo, C. Y., Tanner, A. C. R. \& Ganeshkumar, N. (2003). Cloning and expression of $\alpha$-D-glucosidase and $N$-acetyl- $\beta$-glucosaminidase from the periodontal pathogen, Tannerella forsythensis (Bacteroides forsythus). Oral Microbiol Immunol 18, 309-312.

Imai, M., Murakami, Y., Nagano, K., Nakamura, H. \& Yoshimura, F. (2005). Major outer membrane proteins from Porphyromonas gingivalis: strain variation, distribution, and clinical significance in periradicular lesions. Eur J Oral Sci 113, 391-399.

Inagaki, S., Kuramitsu, H. K. \& Sharma, A. (2005). Contactdependent regulation of a Tannerella forsythia virulence factor, BspA, in biofilms. FEMS Microbiol Lett 249, 291-296.

Ishikura, H., Arakawa, S., Nakajima, T., Tsuchida, N. \& Ishikawa, I. (2003). Cloning of the Tannerella forsythensis (Bacteroides forsythus) siaHI gene and purification of the sialidase enzyme. J Med Microbiol 52, 1101-1107.

Kerosuo, E. (1988). Ultrastructure of the cell envelope of Bacteroides forsythus strain ATCC $43037^{\mathrm{T}}$. Oral Microbiol Immunol 3, 134-137.

Kumagai, Y., Konishi, K., Gomi, T., Yagishita, H., Yajima, A. \& Yoshikawa, M. (2001). Enzymatic properties of dipeptidyl aminopeptidase IV produced by the periodontal pathogen Porphyromonas gingivalis and its participation in virulence. Infect Immun 68, 716-724.

Lee, S.-W., Sabet, M., Um, H. S., Yang, L., Kim, H. C. \& Zhu, W. (2006). Identification and characterization of the genes encoding a unique surface (S-) layer of Tannerella forsythia. Gene 371, 102-111.

Lugtenberg, B., Meijers, J., Peters, R., van der Hoek, P. \& van Alphen, L. (1975). Electrophoretic resolution of the "major outer membrane protein" of Escherichia coli K12 into four bands. FEBS Lett 58, 254-258.

Masters, J. R. (2002). HeLa cells 50 years on: the good, the bad and the ugly. Nature Rev Cancer 2, 315-319.

Moriguchi, K., Higuchi, N., Murakami, Y., Yoshimura, F., Nakamura, H. \& Ohno, N. (2003). A morphological and immunolabeling study of freeze-substituted Bacteroides forsythus. Biotechnol Histochem 78, 129-133.

Munemasa, T., Takemoto, T., Dahlén, G., Hino, T., Shiba, H., Ogawa, T. \& Kurihara, H. (2000). Adherence of Bacteroides forsythus to host cells. Microbios 101, 115-126.

Murakami, Y., Higuchi, N., Nakamura, H., Yoshimura, F. \& Oppenheim, F. G. (2002a). Bacteroides forsythus hemagglutinin is inhibited by $\mathrm{N}$-acetylneuraminyllactose. Oral Microbiol Immunol 17, 125-128.

Murakami, Y., Imai, M., Nakamura, H. \& Yoshimura, F. (2002b). Separation of the outer membrane and identification of major outer membrane proteins from Porphyromonas gingivalis. Eur J Oral Sci 110, 157-162.

Murakami, Y., Imai, M., Mukai, Y., Ichihara, S., Nakamura, H. \& Yoshimura, F. (2004). Effects of various culture environments on expression of major outer membrane proteins from Porphyromonas gingivalis. FEMS Microbiol Lett 230, 159-165.

Nagano, K., Read, E. K., Murakami, Y., Masuda, T., Noguchi, T. \& Yoshimura, F. (2005). Trimeric structure of major outer membrane proteins homologous to OmpA in Porphyromonas gingivalis. J Bacteriol 187, 902-911.

National Committee for Clinical Laboratory Standards (1997). Methods for Antimicrobial Susceptibility Testing of Anaerobic Bacteria, 5th edn, vol. 21. Approved standard M11-A5. Wayne, PA: National Committee for Clinical Laboratory Standards.

Nelson, K. E., Fleischmann, R. D., DeBoy, R. T. \& 20 other authors (2003). Complete genome sequence of the oral pathogenic bacterium Porphyromonas gingivalis strain W83. J Bacteriol 185, 5591-5601.

Nishikawa, K. \& Yoshimura, F. (2001). The response regulator FimR is essential for fimbrial production of the oral anaerobe Porphyromonas gingivalis. Anaerobe 7, 255-262.

Noack, B., Genco, R. J., Trevisan, M., Grossi, S., Zambon, J. J. \& De Nardin, E. (2001). Periodontal infections contribute to elevated systemic C-reactive protein level. J Periodontol 72, 1221-1227.

Sabet, M., Lee, S.-W., Nauman, R. K., Sims, T. \& Um, H.-S. (2003). The surface (S-) layer is a virulence factor of Bacteroides forsythus. Microbiology 149, 3617-3627.

Saito, T., Ishihara, K., Kato, T. \& Okuda, K. (1997). Cloning, expression, and sequencing of a protease gene from Bacteroides forsythus ATCC 43037 in Escherichia coli. Infect Immun 65, 48884891.

Sakamoto, M., Suzuki, M., Umeda, M., Ishikawa, I. \& Benno, Y. (2002). Reclassification of Bacteroides forsythus (Tanner et al., 1986) as Tannerella forsythensis corrig., gen. nov., comb. nov. Int J Syst Evol Microbiol 52, 841-849.

Sára, M. \& Sleytr, U. B. (2000). S-layer proteins. J Bacteriol 182, 859868.

Seshadri, R., Myers, G. S., Tettelin, H., Eisen, J. A., Heidelberg, J. F., Dodson, R. J., Davidsen, T. M., DeBoy, R. T., Fouts, D. E. \& other authors (2004). Comparison of the genome of the oral pathogen Treponema denticola with other spirochete genomes. Proc Natl Acad Sci U S A 101, 5646-5651.

Sharma, A., Sojar, H. T., Glurich, I., Honma, K., Kuramitsu, H. K. \& Genco, R. J. (1998). Cloning, expression, and sequencing of a cell surface antigen containing a leucine-rich repeat motif from Bacteroides forsythus ATCC 43037. Infect Immun 66, 57035710.

Sharma, A., Inagaki, S., Honma, K., Sfintescu, C., Baker, P. J. \& Evans, R. T. (2005). Tannerella forsythia-induced alveolar bone loss in mice involves leucine-rich-repeat BspA protein. J Dent Res 84, 462-467.

Siqueira, J. F., Jr \& Rôças, I. N. (2003). Bacteroides forsythus in primary endodontic infections as detected by nested PCR. J Endod 29, 390-393.

Sleytr, U. B. \& Beveridge, T. J. (1999). Bacterial S-layers. Trends Microbiol 7, 253-260.

Sleytr, U. B. \& Messner, P. (1988). Crystalline surface layers in prokaryotes. J Bacteriol 170, 2891-2897. 
Sleytr, U. B., Messner, P., Pum, D. \& Sára, M. (1993). Crystalline bacterial cell surface layers. Mol Microbiol 10, 911-916.

Socransky, S. S., Haffajee, A. D., Cugini, M. A., Smith, C. \& Kent, R. J., Jr (1998). Microbial complexes in subgingival plaque. J Clin Periodontol 25, 134-144.

Takemoto, T., Kurihara, H. \& Dahlén, G. (1997). Characterization of Bacteroides forsythus isolates. J Clin Microbiol 35, 1378-1381.

Tanner, A. C. R., Listgarten, M. A., Ebersole, J. L. \& Strzempko, M. N. (1986). Bacteroides forsythus sp. nov., a slow-growing, fusiform Bacteroides sp. from the human oral cavity. Int J Syst Bacteriol 36, 213-221.

Ueda, O. \& Yoshimura, F. (2003). Transposon-induced norfloxacinsensitive mutants of Bacteroides thetaiotaomicron. Microbiol Immunol 47, 17-25.

Wang, B., Kraig, E. \& Kolodrubetz, D. (2000). Use of defined mutants to assess the role of the Campylobacter rectus S-layer in bacterium-epithelial cell interaction. Infect Immun 68, 1465-1473.
Wyss, C. (1989). Dependence of proliferation of Bacteroides forsythus on exogenous $\mathrm{N}$-acetylmuramic acid. Infect Immun 57, 1757-1759.

Yano-Higuchi, K., Takamatsu, N., He, T., Umeda, M. \& Ishikawa, I. (2000). Prevalence of Bacteroides forsythus, Porphyromonas gingivalis and Actinobacillus actinomycetemcomitans in subgingival microflora of Japanese patients with adult and rapidly progressive periodontitis. J Clin Periodontol 27, 597-602.

Yoneda, M., Hirofuji, T., Anan, H., Matsumoto, A., Hamachi, T., Nakayama, K. \& Maeda, K. (2001). Mixed infection of Porphyromonas gingivalis and Bacteroides forsythus in a murine abscess model: involvement of gingipains in a synergistic effect. J Periodont Res 36, 237-243.

Yoneda, M., Hirofuji, T., Motooka, N., Nozoe, K., Shigenaga, K., Anan, H., Miura, M., Kabashima, H., Matsumoto, A. \& Maeda, K. (2003). Humoral immune responses to S-layer-like proteins of Bacteroides forsythus. Clin Diagn Lab Immunol 10, 383-387.

Edited by: P. E. Kolenbrander 